\title{
Characteristics of skin coat as well as the physiological status of FI crossing Bali (Bos Sondaicus) $x$ Angus (Bos Taurus) for early identification of adaptability in tropical environment
}

\begin{abstract}
Characteristics of skin and hair color in cattle, as well as the number of skin follicles, have an essential role in the process of adapting to the ambient temperature and humidity. Bali cattle (Bos Sondaicus) is an indigenous Indonesian cattle that is a tropical climate, has the characteristics of the light hair color crossing with Black Angus (Bos Taurus) from different species, subtropical climate.
\end{abstract}

Objective: To know the changes in the skin and hair color characteristics of F1 crossing of Bos Sondaicus with Angus (Bos Taurus), and whether it affects its adaptability to the tropical environment.

Methods: Twenty of F1 Angus x Bali cross cattle were studied for their characteristics of skin and hair color, a number of skin follicles as well as physiological status for early identification of adaptability in a tropical environment. Hair and skin color measured by the value of the RGB (Red, Green, Blue) method. Completely Randomized Design (CRD) was done to distinguish RGB values and the physiological status between crossed compare to local breed.

Results: The results showed that the RGB values of crossed were significantly lower $(\mathrm{P}<0.05)$, had meant that darker and had fewer hair follicles $(\mathrm{P}<0.05)(15.18 \pm 2.24$ vs. $\left.21.38 \pm 4.33 / \mathrm{mm}^{2}\right)$ which caused the skin surface temperature was higher $(\mathrm{P}<0.05)$ $\left(35.41 \pm 1.14\right.$ vs. $\left.34.31 \pm 2.27^{\circ} \mathrm{C}\right)$. Although during the day, they had a higher physiological status $(\mathrm{P}<0.05)$ but still in the normal range.

Conclusion: It concluded that although the skin and hair color became markedly darker, they still can adapt to the tropical environment, shown from body temperature, respiration rate, and pulses, as the gold standard for measures cattle's tolerance to environmental conditions.

Keywords: F1 Angus x Bali crossed cattle, characteristics of skin and hair color, adaptability to the tropical environment

\section{Introduction}

Characteristics of skin and hair color, as well as the number of cow skin follicles in addition to describing genetic characteristics, also have an essential role in the process of adapting to the ambient temperature and humidity. Skin and hair color contribute to reduce or otherwise increase the influence of exposure to heat radiation to the body. ${ }^{1-3}$ The darker the skin color, the more absorbed the heat received from the environment through the process of radiation, ${ }^{4-6}$ received by the surface of the skin causing increased skin surface temperature. ${ }^{7,8}$ The first response of cattle as a heat release business was through the evaporative process; ${ }^{1,9}$ In this process, the role of the number and magnitude of skin follicles becomes essential.

Bali cattle (Bos Sondaicus) is an indigenous Indonesian cattle that is tropical climate, has the characteristics of the hair color of light, that is brownish yellow with white in the buttocks and metatarsus and metacarpus down, make the animal very suitable to the tropical climate. There is an effort to be crossed with bigger breeds that have a larger body size, including Angus. Angus that includes the Bos Taurus, has the characteristics of black hair. How do the changes in the skin and hair color characteristics of F1 crossing from Bos Sondaicus with Bos Taurus, as well as whether it affects its adaptability to the tropical
Volume 6 Issue 3 - 202I

\author{
Teguh Dwi Putra, I\# Panjono Panjono, ${ }^{3 \#}$ \\ Sigit Bintara, ${ }^{2 \#}$ Dyah Tri Widayati, ${ }^{2 \#}$ Endang \\ Baliarti, ${ }^{3 \#}$ Bramada Putra ${ }^{3 \#}$ \\ 'Research assistent of Meat, Draught, and Companion Animal \\ Laboratory, Faculty of Animal Science, Universitas Gadjah Mada, \\ Indonesia \\ ${ }^{2}$ Breeding and Animal Reproduction Department, Faculty of \\ Animal Science, Universitas Gadjah Mada, Indonesia \\ ${ }^{3}$ Animal Production Department, Faculty of Animal Science, \\ Universitas Gadjah Mada, Indonesia \\ "These authors contributed equally to this work
}

Correspondence: Endang Baliarti,Animal Production Department, Faculty of Animal Science, Universitas Gadjah Mada, Fauna Street No. 3 Bulaksumur, Yogyakarta, Indonesia, 55328I, Tel +62-274-563489, Fax +62-274-521578, Email bali_arti@ugm.ac.id

Received: May 17, 2021 | Published: May 28, 2021 environment, have not been studied as an essential consideration in the development of cattle production systems in tropical areas.

The aim of the research:

1) See the change of skin and hair color characteristics as well as skin follicles F1 from the Bali cow, which has a brownish yellow color with Angus bull that has black. The differences tested by scoring using the RGB (Red, Green, Blue) base color scoring method

2) See how the physiological status (respiration, pulse, body temperature, body surface temperature) in F1 results crossing the Bos Sondaicus $x$ the BosTaurus, as early identification of its ability to adapt to the tropical environment.

\section{Materials and methods}

Twenty of the F1 cross-breeding between Angus bull and the Bali cows (AB) and 14 Bali calves (B), aged 10-15 months, were maintained in cages at the farmer's group in the Bungo district of Jambi Indonesia $\left(0^{\circ} 45^{\prime}-2^{\circ} 45^{\prime}\right.$ South Latitude and $101^{\circ} 0^{\prime}-104^{\circ}$ $55^{\prime}$ East Longitude). Environmental conditions include temperature and humidity observed for nine consecutive days using digital 
thermohygrometer ${ }^{10}$ to measure morning temperature (minimum) (at 05.00-09.00 am), daytime (maximum) (at $12.00 \mathrm{am}-4.00 \mathrm{pm}$ ) and night $(8.00 \mathrm{pm}-12.00 \mathrm{pm})$. The environmental data is analyzed using the complete randomized Design, followed by Duncan's multiple range test (DMRT) to know the difference between morning, daytime, and night.

Physiological data include the skin surface temperature for the morning, daytime, and night using infrared thermometer, ${ }^{4,11,12}$ is attached to the forehead, rump, back, and shoulder for 3-4 seconds each (Figure 1). ${ }^{10}$ The measurement is repeated for three times to determine the average skin surface temperature of livestock. Rectal temperature, respiration frequency, and pulse are also performed three times daily in the morning, daytime, and night, for nine consecutive days. The Data obtained is analyzed using the factorial analysis to determine whether there is the influence of the breed, time, and interactions; then followed by Duncan's test.

The characteristics of the hair and skin color on both groups were determined using the 3D paint application to define the color gradient using the RGB (Red, Green, Blue) scoring method. The Data is analyzed descriptive and T-test. The number of skin follicles is done on the part of the rump using USB Digital Microscope 50$500 \mathrm{x}$; subsequent images calibrated using a micrometer calibration ruler microscope.

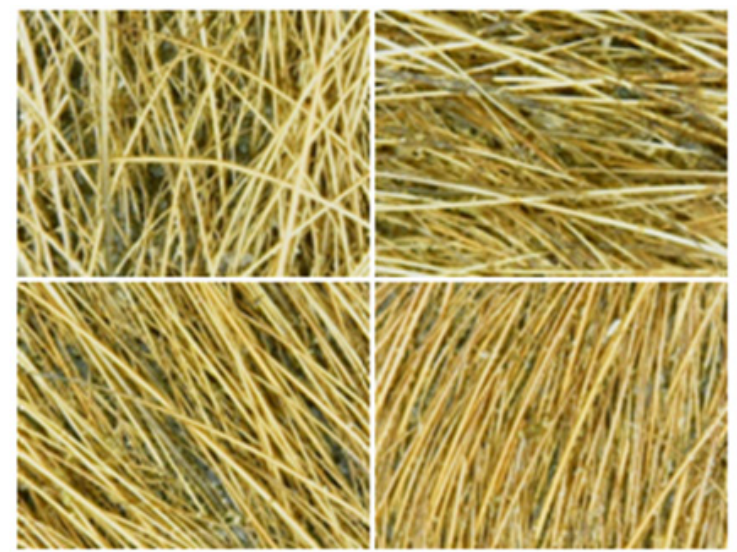

Hair color of Bali cattle (B)

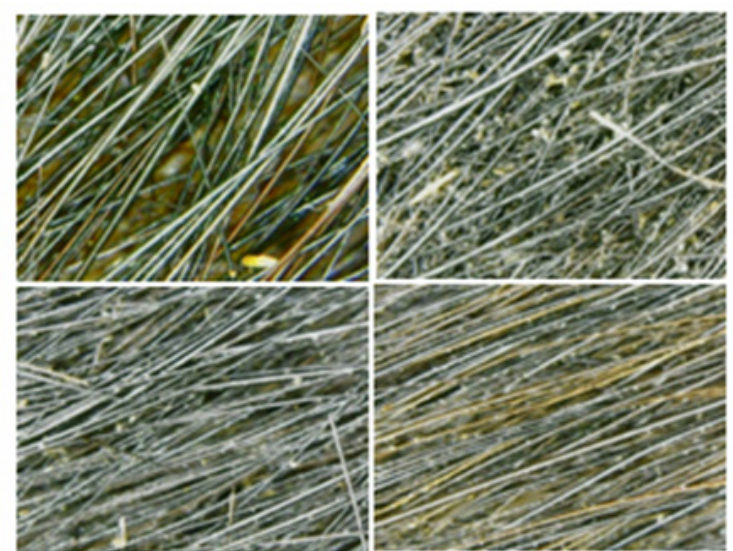

Hair color of F1 crossing Angus x Bali cattle (AB)

Figure I Hair color of Bali cattle (B) compare with FI crossing Angus $\times$ Bali cattle Spacious: $4.2 \times 3.2 \mathrm{~mm}^{2}$.

\section{Results}

\section{Changes in hair color characteristics}

By doing the hair color gradient and the second skin color of the group, the values of $\mathrm{R}, \mathrm{G}$, and $\mathrm{B}$ (Table 1) differ significantly $(\mathrm{P}<0.05)$, the result of the crossing (BA) is darker compared to $\mathrm{B}$ $(\mathrm{P}<0.05)$. Visually, there are different characteristics of hair color as shown in Figure 2.

\section{Changes in the number of skin follicles}

F1 crossing of Bali cow's with Angus bull causes changes in the number of skin follicles; on the F1 crossing Angus x Bali Cattle (AB) is $15.18 \pm 2.24 / \mathrm{mm}^{2}$, less than Bali cattle (B) $21.38 \pm 4.33 / \mathrm{mm}^{2}$ $(\mathrm{P}<0.05)$, with the diameter of the follicles, appear larger (Figure 2).

\section{Environmental conditions}

Ambient temperature (Table 2) at the research location reaches a maximum during the daytime $(\mathrm{P}<0.05)$ resulting from sunlight radiation, unlike in the morning and at night; between morning and at night is no different $(P>0.05)$. In contrast, the humidity in the morning and at night is higher than in the daytime $(\mathrm{P}<0.05)$, such as the temperature and humidity variations shown in tropical areas.

\section{Physiological status}

The results of measurements on the surface skin temperature (Table 3) showed a significant higher at F1 crossing Angus x Bali $(\mathrm{AB})$ than the Bali cattle $(\mathrm{B})(\mathrm{P}<0.05)$ in the morning and at night, but no different during the day $(\mathrm{P}>0.05)$.

Table I Hair and skin color of FI crossing Angus $x$ Bali (AB) compared to Bali cattle (B)

\begin{tabular}{llll}
\hline \multirow{2}{*}{ Groups } & \multicolumn{2}{l}{ Hair color } & \\
\cline { 2 - 4 } & R & G & B \\
\hline AB & $87.03 \pm 53.74^{\mathrm{a}}$ & $70.63 \pm 30.56^{\mathrm{P}}$ & $18.23 \pm 17.67^{\mathrm{x}}$ \\
B & $150.36 \pm 39.15^{\mathrm{b}}$ & $123.29 \pm 36.18^{\mathrm{q}}$ & $47.74 \pm 33.32^{\mathrm{y}}$
\end{tabular}

Skin color

R G B

\begin{tabular}{lllll}
$A B$ & $184.50 \pm 15.69^{a}$ & $187.67 \pm 9.679$ & $172.10 \pm 23.39^{x}$ \\
$B$ & B & $203.20 \pm 33.97^{\mathrm{b}}$ & $209.95 \pm 7.79$ a & $201.98 \pm 12.66^{y}$ \\
\hline
\end{tabular}

a. b.:Different superscripts on the same column show a significant difference $(P<0.05)$

p.q: Different superscripts on the same column show a significant difference $(P<0.05)$

$x . y$ : Different superscripts on the same column show a significant difference $(P<0.05)$

Citation: Putra TD, Panjono P, Bintara S, et al. Characteristics of skin coat as well as the physiological status of FI crossing Bali (Bos Sondaicus) $\times$ Angus (Bos Taurus) for early identification of adaptability in tropical environment. MOJ Eco Environ Sci. 2021;6(3):82-86. DOI: I0.15406/mojes.202I.06.002I9 


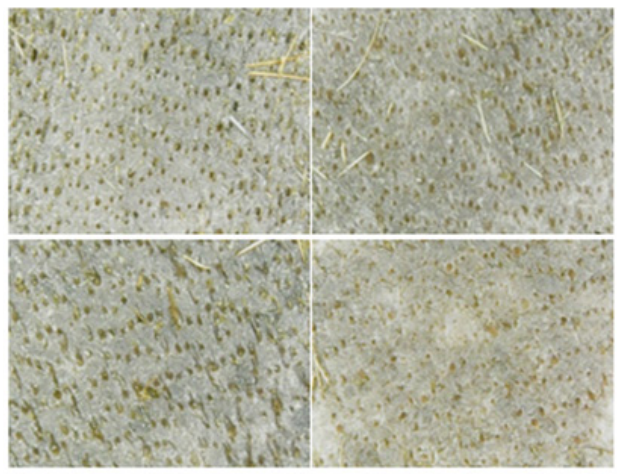

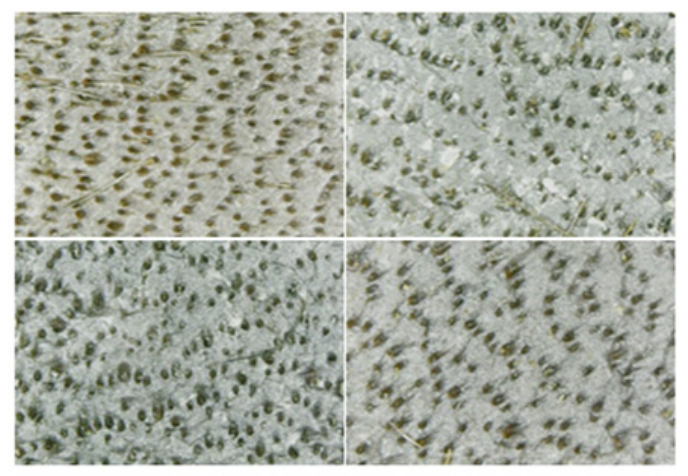

$\mathbf{A B}$

Figure 2 Skin color and number of skin follicles of Bali cattle (B) compare with FI crossing Angus-Bali cattle (AB) Spacious: $4.2 \times 3.2 \mathrm{~mm}^{2}$.

Table 2 Temperature and humidity at the research location

\begin{tabular}{lllll}
\hline & \multicolumn{2}{l}{ Waktu } & & \\
\cline { 2 - 4 } & Morning & Daytime & Night & \multirow{2}{*}{ Average } \\
\cline { 2 - 4 } & $\mathbf{0 5 . 0 0 - 0 9 . 0 0 \mathrm { am }}$ & $\mathbf{1 2 . 0 0 \mathrm { am } - 0 4 . 0 0 \mathrm { pm }}$ & $\mathbf{0 8 . 0 0 - 1 2 . 0 0 \mathrm { pm }}$ & \\
\hline Temperature $\left({ }^{\circ} \mathrm{C}\right)$ & $25.66 \pm 0.90^{\mathrm{a}}$ & $31.82 \pm 2.30^{\mathrm{b}}$ & $26.94 \pm 0.62^{\mathrm{a}}$ & $28.14 \pm 3.05$ \\
Humidity $(\%)$ & $92.87 \pm 3.41^{\mathrm{a}}$ & $65.00 \pm 14.25^{\mathrm{b}}$ & $91.96 \pm 2.63^{\mathrm{a}}$ & $83.27 \pm 15.55$ \\
\hline
\end{tabular}

a. b: Different superscripts on the same line show a significant difference $(P<0.05)$

Table 3 Body surface temperature. rectal temperature. respiration frequency. and pulse of cross Angus-Bali cattle (AB) compared to Bali cattle (B) in the tropical environment

\begin{tabular}{|c|c|c|c|c|}
\hline \multirow{2}{*}{ Breed } & \multicolumn{4}{|l|}{ Time } \\
\hline & Morning & Daytime & Night & Average \\
\hline \multicolumn{5}{|c|}{ Body surface temperature } \\
\hline$A B$ & $35.0 \pm 1.0^{c}$ & $36.6 \pm 0.4^{d}$ & $34.6 \pm 0.6^{c}$ & $35.4 \pm 1 . I^{9}$ \\
\hline B & $32.6 \pm 1.0^{\mathrm{a}}$ & $37.0 \pm 1.6^{d}$ & $33.3 \pm 1.0^{b}$ & 34. $3 \pm 2.3^{p}$ \\
\hline Average & $34.0 \pm 1.5^{x}$ & $36.8 \pm I . I^{y}$ & $34.1 \pm 1.0^{x}$ & \\
\hline \multicolumn{5}{|c|}{ Body temperature } \\
\hline$A B$ & $38.2 \pm 0.4^{b}$ & $38.7 \pm 0.2^{\mathrm{bc}}$ & $38.6 \pm 0.6^{c}$ & $38.5 \pm 0.4^{9}$ \\
\hline B & $37.5 \pm 0.3^{\mathrm{a}}$ & $38.7 \pm 0.2^{c}$ & $37.6 \pm 0.7^{\mathrm{a}}$ & $37.9 \pm 0.7^{p}$ \\
\hline Average & $37.9 \pm 0.1^{x}$ & $38.7 \pm 0.2^{y}$ & $38.2 \pm 0.8^{x}$ & \\
\hline \multicolumn{5}{|c|}{ Respiration rate } \\
\hline$A B$ & $30.6 \pm 4.9^{c}$ & $33.1 \pm 9.3^{c}$ & $29.0 \pm 4.7^{c}$ & $30.9 \pm 6.79$ \\
\hline B & $22.6 \pm 5.3^{b}$ & $37.4 \pm 4.4^{\mathrm{d}}$ & $17.6 \pm 2.0^{\mathrm{a}}$ & $25.9 \pm 9.4 \mathrm{P}$ \\
\hline Rerata & $27.4 \pm 6.4^{x}$ & $34.8 \pm 7.9 y$ & $24.3 \pm 6.8^{x}$ & \\
\hline \multicolumn{5}{|l|}{ Pulses } \\
\hline$A B$ & $61.7 \pm 6.2^{\mathrm{abc}}$ & $60.0 \pm 6.6^{\mathrm{abc}}$ & $67.7 \pm 7.2^{c}$ & $63.1 \pm 7.5^{9}$ \\
\hline B & $55.5 \pm 10.6^{\mathrm{a}}$ & $64.5 \pm 11.3^{\mathrm{bc}}$ & $59.1 \pm 8.8^{\mathrm{ab}}$ & $59.7 \pm 10.79$ \\
\hline Average & $59.1 \pm 8.9^{x}$ & $61.9 \pm 8.9^{x y}$ & $64.1 \pm 8.8^{y}$ & \\
\hline
\end{tabular}

$a, b, c, d$ : Different superscripts on the same line show a significant difference $(P<0.05)$

$x, y$ : Different superscripts on the same line show a significant difference $(P<0.05)$

$p, q$ : Different superscripts on the same collum show a significant difference $(P<0.05)$

\section{Discussion}

The R, G, B scores of F1 Angus x Bali are lower $(\mathrm{P}<0.05)$ compared to Bali cattle, indicating that cross cattle have darker skin and hair color (Figure 2). The darker color derived from the black color of Angus bull, but apparently, the black color of Angus bull crossed with a brownish yellow color of Bali cows, causing the F1 to change its color, but not as black as the Angus.

Citation: Putra TD, Panjono P, Bintara S, et al. Characteristics of skin coat as well as the physiological status of FI crossing Bali (Bos Sondaicus) $\times$ Angus (Bos Taurus) for early identification of adaptability in tropical environment. MOJ Eco Environ Sci. 2021;6(3):82-86. DOI: 10.15406/mojes.2021.06.00219 
With the change of skin and hair color characteristics to be darker received heat loads become larger ${ }^{5}$ because darker color is better in absorbing heat from the environment, causing an increase in body surface temperature $(\mathrm{P}<0.05)$ (Table 1). The question is, does this darker color F1 crossing Angus x Bali has the same ability to adapt to the tropical environment?

The ambient temperature at the research location reaches the peak during the daytime at $12.00 \mathrm{am}-2.00 \mathrm{pm}$ (Table 2) at the time of the solar radiation reaches the maximum. ${ }^{13-15}$ The heat of the environment received by the darker surface of the crossed cattle, causing a higher surface temperature $(\mathrm{P}<0.05)$. Higher heat absorption is transmitted into the body, causing the body temperature is also higher $(\mathrm{P}<0.01)$. The most effective way to reduce the heat load from the body is through the evaporation process, one of them through sweating. The size of skin follicles influences the magnitude of the memory. The result of the crossing shows more prominent hair follicles (Figure 2). With the larger follicles, the evaporation process becomes better.

From Table 3 the average body temperature of the crossed cattle is higher $0.6^{\circ} \mathrm{C}(\mathrm{P}<0.01)$ than the local breed; other than the possibility of higher heat absorption, higher temperature also likely caused by having a larger body frame because the metabolism process is higher causing the heat production to be higher. Differences in the morning, daytime, and night causing environmental temperature changes; the difference is about $6^{\circ} \mathrm{C}$ between morning-daytime and $5^{\circ} \mathrm{C}$ between daytime and night (Table 1). Due to the ambient temperature difference, it creates a slight fluctuation of body temperature but differs phenomenon between the crossed with the local cattle. During the day, when the ambient temperature rises $6^{\circ} \mathrm{C}$, the body temperature of the local breed rises higher than in the morning; not so for the crossbreed. Although during the daytime, the ambient temperature increases significantly, the body temperature of the crossed cattle is no different from the morning. This fact shows that animals make various attempts to release heat loads, which are likely through the process of respiration by taking a colder air temperature as much as possible from the environment to be circulated to all parts of the body. ${ }^{16,17}$ The effort cause the frequency of pulse to increase (Table 3$):{ }^{18}$ the crossed has a frequency of respiration and pulses higher. Crossed can produce better heat through effective evaporation mechanisms as they have a higher characteristic of skin follicles. It differs phenomenon in local cattle, which is body temperature rises $1^{\circ} \mathrm{C}$ higher $(<0.05)$ during the daytime and should increase the frequency of pulses (Table 3 ) to lower the body temperature to $37^{\circ} \mathrm{C}$. At night, the cross can maintain its body temperature around $38^{\circ} \mathrm{C}$ because by having a proportion of $50 \%$ blood Taurus, the animal has a thicker skin as a body heat insulation. The heat production mechanism is in line with the frequency of pulses. The frequency of pulses of crossed for daytime and night is higher $(<0.05)$ (Table 3$)$, to secrete body heat through evaporation mechanisms. With thermoregulation through the setting of breath and evaporation frequency, the crossed can maintain the homeostatic well, without having to involve significant changes in the pulse.

\section{Conclusion}

a. The skin and hair color characteristics in F1 result from crossing local Bali cattle with Angus bull became markedly darker than local breed, with fewer skin follicles but larger.

b. Although F1 skin and hair character change results to be darker it still can adapt to the tropical environment, shown from body temperature, respiration rate, and pulses, as the gold standard for measures cattle's tolerance to environmental conditions.

\section{Acknowledgments}

The author thank to the farmer's community in the district of Pelerilir, Bungo Regency, Jambi Province Indonesia for livestock lending, Inseminator, and the District livestock Office, which has provided technical assistance in the field, and also to scholarships LPDP for funding support during research.

\section{Funding}

None.

\section{Conflicts of interest}

We certify that there is no conflict of interest with any financial organization regarding the material discussed in the manuscript.

\section{References}

1. Berman A. Invited review: Are adaptations present to support dairy cattle productivity in warm climates? J Dairy Sci. 2011;94(5):2147-2158.

2. Castanheira M, Paiva SR, Louvandini H, et al. Use of heat tolerance traits in discriminating between groups of sheep in central Brazil. Trop Anim Health Prod. 2010;42(8):1821-1828.

3. Fanta M. Physiological adaptation of holstein frisian dairy cattle in Ethiopia: Review article. J Biol Agric Healthc. 2017;7(13):67-78.

4. Hillman PE, Lee CN, Carpenter JR, et al. Impact of hair color on thermoregulation of dairy cows to direct sunlight. ASAE Annual Meeting; 2001 .

5. Pocay PLB, Pocay VG, Starling JMC, et al. Physiological responses of predominantly white and predominantly black holstein cows under direct solar radiation. Ars Vet. 2001;17(2):155-161.

6. Troxel TR, Gadberry MS, Beck PA. Temperature, relative humidity, and dew point of 6 commercial trailer compartments during summer transportations of beef calves in the mid-South. Prof Anim Sci. 2016;32(4):461-469.

7. Berman A. Tissue and external insulation estimates and their effects on prediction of energy requirements and of heat stress. J Dairy Sci. 2004;87(5):1400-1412.

8. Athar M. Oxidative stress and experimental carcinogenesis. Indian J Exp Biol. 2002;40(6):656-667.

9. Gebremedhin KG, Wu B. Simulation of sensible and latent heat losses from wet-skin surface and fur layer. J Therm Biol. 2002;27(4):291-297.

10. Aditia EI, Yani A, Fatonah AF. Physiological response of bali cattle to oil palm integration system based on microclimate environment conditions. 2017;05(1):23-28.

11. Maia ASC, Gomes da Silva R, Bertipaglia ECA. Environmental and genetic variation of the effective radiative properties of the coat of Holstein cows under tropical conditions. Livest Prod Sci. 2005;92(3):307-315.

12. Shiota AM, Santos SF dos, Nascimento MRB dM, et al. Physiological parameters, hair coat characteristics and thermal gradients in nellore heifers in summer and winter in tropical environment. Biosci $J$. 2013;29(1):1687-1695.

13. Hansen P. Physiological and cellular adaptations of zebu cattle to thermal stress. Anim Reprod Sci. 2004;82-83:349-360.

14. Yani A, Suhardiyanto H, Hasbullah R, et al. Analysis and simulation of air temperature distribution in dairy cowsheds using computational fluid dynamics (CFD). Media Peternak. 2007;30(3):218-228.

15. Serang PM, Suartha IN, Arjentinia IPGY. Respiration frequency of adult female bali cows at cattle breeding centers. 2016;8(1):25-29. 
16. Yani A, Purwanto BP. Effects of microclimate on physiological responses of fries holland cattle and environmental modifications to increase their productivity (REVIEW). Media Peternak. 2006;29(1):35-46.

17. Tucker CB, Weary DM, Fraser D. Influence of neck-rail placement on free-stall preference, use, and cleanliness. J Dairy Sci. 2005;88(8):27302737.
18. Tucker CB, Rogers AR, Schütz KE. Effect of solar radiation on dairy cattle behaviour, use of shade and body temperature in a pasture-based system. Appl Anim Behav Sci. 2008;109(2-4):141-154. 